\title{
IDENTIDADES FRATURADAS: VARIAÇÕES DO DUPLO EM DOIS IR- MÃos, DE MiLTON Hatoum
}

Flávio PEREIRA CAMARGO*

Alex BRuno DA SILVA**

\section{RESUMO}

Neste artigo, propomos uma análise das variações do mito do duplo no romance Dois irmãos, de Milton Hatoum, publicado em 2000. Com base nos pressupostos teórico-críticos de Bravo (1997), Rank (2013), Bachelard (1993), Rosset (1999) e Freud (1996), pretendemos demonstrar que, para além do tema dos irmãos gêmeos, o duplo, em Dois irmãos, pode ser lido em mais dois aspectos de duplicidade: a configuração do narrador, que tenta definir sua identidade como espelho do outro, e a imagem da casa em ruínas, espaço que reflete duplamente a decadência da família libanesa, bem como a identidade cultural do imigrante em terra alheia.

PALAVRAS-CHAVE: gêmeos, narrador, espaço, memória.

Eu não sou eu nem sou o outro, Sou qualquer coisa de intermédio: Pilar da ponte de tédio Que vai de mim para o outro (Mário de Sá Carneiro)

A noção de desdobramento do eu, recorrente na literatura, pode ser vista como um dos temas mais inquietantes diante do questionamento da identidade única do sujeito. Para Ana Maria Lisboa de Mello (2000, p. 111), o tema do duplo na criação literária pode "apresentar-se sob múltiplas formas, desdobrando-se em sósias, irmãos - gêmeos ou não

* Doutorado em Letras e Linguística pela Universidade Federal de Goiás (UFG), Goiânia, Goiás, Brasil. E-mail: camargolitera@gmail.com.

** Mestrado em Letras e Linguística pela Universidade Federal de Goiás (UFG), Goiânia, Goiás, Brasil. E-mail: alexprofessor100@gmail.com. 
-, representado, também, pela sombra, o retrato ou a imagem refletida no espelho".

O vocábulo duplo ficou consagrado pelo movimento romântico por meio do escritor alemão Jean-Paul Richter que, em 1796, cunhou o termo Doppelgänger. Nicole Bravo (1997, p. 261) afirma que se traduz o termo por "duplo" ou "segundo eu", com o sentido de "companheiro de estrada", "aquele que caminha ao lado". A autora aponta a ideia de duplicidade relacionada a uma experiência subjetiva e, diante desse paradigma, o tema do duplo assume perspectivas distintas em diferentes momentos históricos.

Os estudos sobre o duplo e sua representação literária podem, de acordo com Bravo (1997), ser divididos em quatro momentos historicamente localizados: da Antiguidade ao século XVI, final do século XVI, século XIX e século XX. A autora parte da noção de unicidade do eu e chega ao pensamento da fragmentação do sujeito:

Desde a Antiguidade até o final do século XVI, esse mito [do duplo] simboliza o homogêneo, o idêntico: a semelhança física entre duas criaturas é usada para efeitos de substituição, de usurpação de identidade, o sósia, o gêmeo é confundido com o herói e vice-versa, cada um com sua identidade própria. A tendência à unidade prevalece também quando um personagem desempenha dois papéis.

A partir do término do século XVI, o duplo começa a representar o heterogêneo, com a divisão do eu chegando à queda da unidade (século XIX) e permitindo até mesmo um fracionamento infinito (século XX) (BRAVO, 1997, p. 263-264).

Percebem-se, nesse excerto, duas representações do duplo literário. Na primeira representação, centrada na figura do homogêneo, a identidade do sujeito que se vê duplicado não é colocada em questionamento, em contrapartida, a figura do duplo heterogêneo apresenta as inconstâncias do ser humano cindidas em personagens que se desdobram em diferentes "eus". O exemplo mais comum da representação do duplo homogêneo é o caso dos irmãos gêmeos ou sósias, no qual o duplo estabelece uma substituição apenas momentânea. Já no duplo heterogêneo, os conflitos representados são de um único ser em busca de si mesmo. 
O duplo como representação de uma cisão interna é bastante recorrente na contemporaneidade. A noção do desdobramento do Eu, a partir do século XX, privilegia os aspectos psicológicos e questiona a identidade pessoal - vista por muito tempo como indivisível -, passando a revelar-se em identidades múltiplas.

Logo, os estudos da psicologia e da psicanálise apontam reflexões sobre a representação desse sujeito em conflito consigo mesmo. Sigmund Freud (1996, p. 258), por exemplo, em $O$ estranho, vê nesse fenômeno a representação da dualidade da psique humana: o estranho não é nada de novo ou alheio, porém, algo que é familiar e há muito estabelecido na mente, e que somente se alienou desta através do processo da repressão, ou seja, "algo que deveria permanecer oculto mas veio à luz".

Otto Rank(2013), assim como Freud, aborda o tema da duplicidade do eu sob o aspecto psicológico. O duplo, segundo Rank (2013, p. 128), é o resultado das partes que o eu despreza, mas que retornam de forma ameaçadora, isto é, o duplo "torna reais os desejos secretos e sempre reprimidos de sua alma". As personagens se desdobram e sofrem um conflito psíquico, criando o duplo como forma de libertação.

Diante das reflexões sobre o duplo, a problemática da identidade pessoal e cultural aparece no conflito entre o interior e o exterior, deslocando a noção de unidade para a ideia de alteridade. É Stuart Hall (2006) quem chama a atenção para uma revisão do conceito da identidade, questionando a noção de integridade e estabilidade. O sujeito contemporâneo, nas palavras do teórico, é "composto não de uma única, mas de várias identidades, algumas vezes contraditórias ou não resolvidas" (HALL, 2006, p. 12). O teórico jamaicano, em seu livro $A$ identidade cultural na pós-modernidade, apresenta algumas questões da identidade cultural, contemplando os conceitos de sujeito e identidade nos dias de hoje. Para isso, são debatidos, no livro, temas como a crise de identidade do sujeito, o deslocamento do sujeito, a questão das identidades nacionais e a influência da globalização no hibridismo e no reforço das identidades.

Com o objetivo de explicar que, a partir da modernidade, há uma espécie de crise da identidade, Hall (2006, p.12) afirma, segundo a perspectiva dos estudos culturais, que, em uma sociedade pós-moderna, ${ }^{1}$ a identidade é "móvel", pois cada indivíduo, em 
determinadas circunstâncias, se posicionará de acordo com a identidade que melhor o identifique. Inserido nessa perspectiva, o romance Dois irmãos apresenta um jogo de identidades amalgamadas às lembranças do narrador-personagem, possibilitando a representação de variações do mito do duplo no decorrer da narrativa.

O romance retoma o tema dos irmãos gêmeos, fundamentandose em dois episódios bíblicos²: o ódio entre os irmãos Caim e Abel, num jogo de oposição baseado no sacrifício que estes apresentam a Deus, e, também, na história de Esaú e Jacó, irmãos gêmeos do livro de Gênesis. Além das histórias bíblicas, o romance de Hatoum dialoga com a narrativa machadiana que, repetindo os nomes bíblicos Esaú e Jacó, centra-se nos topos dos gêmeos diferentes e no ódio que se fortalece na trama.

Para além dos conflitos entre os irmãos gêmeos, o duplo, em Dois irmãos, pode ser lido em mais dois aspectos: a configuração do narrador, que tenta definir sua identidade como espelho do outro, e a imagem da casa em ruínas, em que o espaço reflete duplamente a decadência da família libanesa, bem como a identidade cultural do imigrante em terra alheia. Nesse sentido, é relevante refletir como o duplo é construído a partir do tema clássico dos irmãos gêmeos e se estende, no interior da narrativa, por meio da composição do estatuto do narrador e da representação dos espaços físico-geográficos.

O tema da duplicidade do eu justifica-se pelo próprio título do romance - Dois irmãos. Partindo da figura dos irmãos gêmeos, o eixo central da narrativa é a luta travada entre Yaqub e Omar pelo amor da mãe, que favorece continuamente um irmão mais que o outro. Dessa forma, num primeiro nível, os irmãos Yaqub e Omar, apesar da semelhança física, apresentam personalidades distintas, mas complementares. A narrativa é construída de forma estilhaçada pelas memórias de Nael. O relato desse narrador inicia com a derrocada da família libanesa e a dor da mãe, que, no leito de morte, indaga sobre os filhos: "Meus filhos já fizeram as pazes? Repetiu a pergunta com a força que lhe restava, com a coragem que a mãe aflita encontra na hora da morte" (HATOUM, 2000, p. 12).

Anuncia-se, assim, a rivalidade entre os irmãos Yaqub e Omar, que é revelada com o desenrolar da narrativa. Acompanhando a memória do narrador, em uma teia discursiva que embaralha os eventos, 
são apresentadas as diferenças de comportamento e personalidade entre os irmãos. Enquanto Omar, o caçula, era educado com excessivo zelo e carinho por parte da mãe Zana, Yaqub crescia sob os cuidados de Domingas, "a cunhatã mirrada, meio escrava, meio ama, 'louca para ser livre' [...]" (HATOUM, 2000, p. 67).

O primeiro capítulo do romance evidencia as semelhanças físicas entre os irmãos e as desavenças que marcam a separação de ambos. A chegada de Yaqub do Líbano, após cinco anos longe de casa, é evocada pelo narrador e, assim, os anos de separação não foram capazes de amenizar grandes semelhanças:

Agora ele [Yaqub] estava de volta: um rapaz tão vistoso e alto quanto o outro filho, o Caçula. Tinham o mesmo rosto anguloso, os mesmos olhos castanhos e graúdos, o mesmo cabelo ondulado e preto, a mesmíssima altura. Yaqub dava um suspiro depois do riso, igualzinho ao outro. A distância não dissipara certos tiques e atitudes comuns, mas a separação fizera Yaqub esquecer certas palavras da língua portuguesa (HATOUM, 2000, p. 16).

Percebe-se que a semelhança entre Yaqub e Omar é intensificada pelo narrador, "porque, juntos, pareciam a mesma pessoa" (HATOUM, 2000, p. 25). Apesar de a narrativa ser construída de modo a apresentar as semelhanças físicas entre os irmãos, é no contraste dos traços psicológicos que a noção de duplo surge com maior intensidade. Yaqub, ao retornar a Manaus e reencontrar as lembranças da infância, é tomado por um silêncio e, desse vazio, o narrador começa a traçar as diferenças de personalidade dos gêmeos:

Quando chovia, os dois trepavam na seringueira do quintal da casa, e o Caçula trepava mais alto, se arriscava, mangava do irmão, que se equilibrava no meio da árvore, escondido na folhagem [...]. Não, fôlego ele não tinha pra acompanhar o irmão. Nem coragem. Sentia raiva, de si próprio e do outro, quando via o braço do Caçula enroscado no pescoço de um curumim do cortiço que havia nos fundos da casa. Sentia raiva de sua impotência e tremia de medo, acovardava, ao ver o Caçula desafiar três ou quatro moleques parrudos, aguentar o cerco e os socos deles e revidar com fúria e palavrões. Yaqub se escondia, mas não deixava de admirar a coragem de Omar. Queria brigar como ele, sentir o rosto inchado, o gosto de sangue na boca, 
a ardência no lábio estriado, na testa e na cabeça cheia de calombos; queria correr descalço, sem medo de queimar os pés nas ruas de macadame aquecidas pelo sol forte da tarde, e saltar para pegar a linha ou a rabiola de um papagaio que planava lentamente, em círculos, solto no espaço. O Caçula tomava impulso, pulava, rodopiava no ar como um acrobata e caía de pé, soltando um grito de guerra e mostrando as mãos estriadas. Yaqub recuava ao ver as mãos do irmão cheias de sangue, cortadas pelo vidro de cerol (HATOUM, 2000, p. 17-18).

O trecho transcrito demonstra que os irmãos têm personalidades distintas, mas integrantes. Esse jogo entre semelhanças e diferenças aponta para a reflexão sobre o duplo - os limites entre ser o mesmo e/ ou o outro, diferente ou semelhante, como se a vida de um dependesse da do outro. Omar é destemido, corajoso e com talentos para gozar dos prazeres mundanos; por outro lado, Yaqub é tímido, calado, calculista e estuda para ser bem-sucedido. As imagens que são apresentadas dos irmãos gêmeos, semelhantes fisicamente e opostos no que se refere aos traços subjetivos de suas personalidades, representam duas faces constituintes do sujeito.

As desavenças entre os irmãos tornam-se mais acentuadas à medida que eles crescem e, então, a sequência de encontros dos gêmeos com Lívia - menina pela qual os irmãos apaixonam-se - culmina no ódio entre eles. Em uma sessão de cinematógrafo, relembrada pelo narrador, uma pane no gerador apaga as imagens do recinto e, quando alguém abre uma janela, a plateia vê os lábios de Lívia grudados no rosto de Yaqub. O resultado é a fúria de Omar: "Depois, o barulho de cadeiras atiradas no chão e o estouro de uma garrafa estilhaçada, e a estocada certeira, rápida e furiosa do Caçula" (HATOUM, 2000, p. 28). Após esse conflito, Yaqub, ferido pelo irmão, permanece com uma cicatriz no rosto que, fisicamente, marca uma diferença entre os gêmeos e simboliza uma cisão do duplo.

O centro da rivalidade entre Omar e Yaqub é o amor por Lívia. Segundo Rank (2013), a catástrofe das personagens de histórias de duplo liga-se a uma mulher. Sendo assim, a relação conturbada entre os gêmeos se inicia na luta pelo coração de Lívia e pelo amor da mãe, acentuando-se, na narrativa, gradativamente, nas diferenças de comportamento e nas escolhas feitas. 
Rank (2013) postula que as visões culturais sobre os gêmeos, desde a Antiguidade, recaem sobre a concepção dualista da alma, demonstrando, portanto, a imortalidade individual. O irmão mais novo, muitas vezes, é como uma imagem refletida, "um rival em tudo que aquele vê, sente e pensa" (RANK, 2013, p. 127). Enquanto Omar é o filho preferido de Zana, Yaqub é rejeitado logo na infância e mandado para o Líbano. Isso se reflete na descrição psicológica que o narrador constrói dos irmãos:

Esse Yaqub, que embranquecia feito osga em parede úmida, compensava a

ausência dos gozos do sol e do corpo aguçando a capacidade de calcular, de equacionar. No colégio dos padres ele encontrava sempre, antes de qualquer um, o valor de um z, y ou x. Surpreendia os professores: a chave da mais complexa equação se armava na cabeça de Yaqub, para quem o giz e o quadro-negro eram inúteis.

O outro, o Caçula, exagerava as audácias juvenis: gazeava lições de latim, subornava porteiros sisudos do colégio dos padres e saía para a noite, fardado, transgressor dos pés ao gogó, rodando os salões da Maloca dos Barés, do Acapulco, do Cheik Clube, do Shangri-Lá. De madrugada, na hora do último sereno, voltava para casa. E lá estava Zana, impávida na rede vermelha, no rosto a serenidade fingida, no fundo atormentada, entristecida por passar mais uma noite sem o filho (HATOUM, 2000, p. 32-33).

Os gêmeos representam a dualidade presente em todo ser humano. A descrição antagônica das personalidades de Yaqub e Omar figura-se, aparentemente, como a luta entre o bem e o mal. Por um lado, o narrador apresenta Yaqub como o bom garoto que ingressa na Escola Politécnica e, posteriormente, forma-se na Universidade, tornando-se engenheiro - o filho educado, centrado e bem organizado que constitui uma família.

Por outro lado, Omar configura-se como a representação do lado mau, o filho que é reprovado na escola e é violento com os professores. É o caçula, mimado pela mãe, que só quer saber de gozar os prazeres da vida - um boêmio aventureiro. Os conflitos existentes entre os gêmeos, cada um tendo que conviver com seu duplo, contribui para reforçar que a personalidade de um complementa a do outro, portanto, não há duelo 
entre o bem e o mal. Yaqub e Omar, baseados em valores diferentes, encontram destinos opostos e, tanto um quanto o outro, lutam contra uma ruína pessoal.

O confronto entre os gêmeos intensifica-se na narrativa quando Omar, o caçula, a mando da mãe Zana, vai passar um tempo com o irmão em São Paulo para estudar. Omar, ao ver Yaqub bem-sucedido como engenheiro e casado com Lívia, o amor da infância, rouba o dinheiro do irmão e foge para os Estados Unidos. Yaqub, então, prepara um plano silencioso para vingar-se: "Não tinha perdoado a agressão do irmão na infância, a cicatriz. Isso nunca tinha saído da cabeça dele. Jurou que um dia ia se vingar" (HATOUM, 2000, p. 125).

Ao final da narrativa, quando Zana envia uma carta ao filho engenheiro, sugerindo que ele e o irmão trabalhassem juntos na construção de um hotel em Manaus, Yaqub parece ignorar o pedido da mãe, porém, associa-se ao indiano chamado Rochiram às escondidas, traindo Omar, que já havia consolidado parceria com o indiano na construção do prédio:

O sonho de Zana, desfeito: ver os filhos juntos, numa harmonia impossível. Ela relembrava o seu plano, minucioso e sagaz. "Meus filhos iam abrir uma construtora, o Caçula ia ter uma ocupação, um trabalho, eu tinha certeza..." Chamava minha mãe para perto dela, dizia: "O Omar perdeu a cabeça, foi traído pelo irmão. Sei de tudo, Domingas... Yaqub se reuniu com aquele indiano, fez tudo escondido, ignorou o meu Caçula, estragou tudo..." Domingas ouvia e se afastava, deixava a outra sozinha, maldizendo a trama de Yaqub (HATOUM, 2006, 176).

Depois do golpe, Omar espanca o irmão a ponto de Yaqub precisar ser hospitalizado. Em seguida, Yaqub persegue Omar e decide contratar um advogado para processá-lo, almejando sua prisão. O ódio entre os irmãos é reforçado no fim do romance, não havendo possibilidades de perdão ou convivência e, assim, Zana observa sua família desmoronar e sonha com a reconciliação dos filhos: "Não queria morrer vendo os gêmeos se odiarem como dois inimigos. Não era mãe de Caim e Abel. Ninguém havia conseguido apaziguá-los, nem Halim, nem as orações, nem mesmo Deus" (HATOUM, 2000, p. 227-228). 
Para a crítica Leyla Perrone-Moisés (2007, p. 285), em seu ensaio "A cidade flutuante": na narrativa de Hatoum, Yaqub e Omar têm personalidades e destinos muito diferentes, "sem que o romancista caia na facilidade de alegorizá-los de modo maniqueísta" como oposição da felicidade à infelicidade e, com isso, o desfecho do romance não apresenta utopias.

Dito isto, o segundo nível do duplo, em Dois irmãos, revela-se na configuração do narrador Nael: dividido entre dois mundos, duas identidades, centro para onde converge uma variedade de lembranças alheias que operam no discurso narrativo, a origem de Nael encontrase cindida. Na busca de encontrar seu pai entre os gêmeos da casa de Halim, o narrador está diante de conflitos interiores representados sempre pela imagem do outro.

Nesse sentido, a narração memorialística de Nael configura-se como um jogo de duplicidades que apresenta a relação entre o Eu e o Outro. A construção da identidade desse narrador demonstra uma espécie de processo duplo - de um lado, o drama individual da origem, confluindo na imagem de si mesmo diante do outro e, de outro lado, a esfera social das diferenças culturais e sociais: "Adiei a pergunta sobre meu nascimento. Meu pai. Sempre adiaria, talvez por medo. Eu me enredava em conjecturas, matutava, desconfiava de Omar, dizia a mim mesmo: Yaqub é meu pai, mas também podia ser o Caçula" (HATOUM, 2000, p. 133).

Filho da empregada Domingas com um dos gêmeos da casa, a identidade de Nael é móvel. No seu livro Identidade (2005, p. 17), Zygmunt Bauman aponta para o caráter ambivalente no que tange ao processo de definição de si mesmo, em contato com um "mundo de diversidade e policultura". Os dilemas em torno da identidade perpassam o discurso do narrador Nael e, por vezes, a memória entrelaçada ao esquecimento proporciona a imaginação de identidades flutuantes e "de lembranças, de um passado desconhecido, jogado sei lá em que praia de rio" (HATOUM, 2000, p. 91). Nesse sentido, é relevante destacar que:

a "identidade" só nos é revelada como algo a ser inventado e, não descoberto; como alvo de um esforço, "um objetivo"; como uma coisa que ainda se precisa construir a partir do zero ou escolher entre alternativas e então lutar por ela e protegê-la lutando ainda 
mais - mesmo que, para que essa luta seja vitoriosa, a verdade sobre a condição precária e eternamente inconclusa da identidade deva ser, e tenda a ser, suprimida e laboriosamente oculta (BAUMAN, 2005, p. 21-22).

O narrador de Dois irmãos, situado de forma pungente a partir de um ponto de vista determinado, tem, no entanto, uma característica peculiar, que se refere ao fato de que Nael, aparentemente, nem é o protagonista da sua narrativa, nem é um mero observador, ele está entre as duas coisas e é as duas coisas ao mesmo tempo. Nesses termos, esse narrador procura na ambivalência que os gêmeos representam reconstituir o fio da própria vida. A rejeição do narrador em relação à imagem do gêmeo mais novo é reforçada quando revela-se, na narrativa, que Omar, em uma noite, estuprara a empregada Domingas, a mãe de Nael:

Ela [Domingas] me enlaçou, beijou meu rosto e abaixou a cabeça. Murmurou que gostava tanto de Yaqub... Desde o tempo em que brincavam, passeavam. Omar ficava enciumado quando via os dois juntos, no quarto, logo que o irmão voltou do Líbano. "Com o Omar eu não queria... Uma noite ele entrou no meu quarto, fazendo aquela algazarra, bêbado, abrutalhado... Ele me agarrou com força de homem. Nunca me pediu perdão".

Ela soluçava, não podia falar mais nada (HATOUM, 2000, p. 241).

Não é por acaso, então, que esse narrador descreve os gêmeos com comportamento e caráter distintos. O fascínio de Nael por Yaqub pode ser explicado em razão do ódio e do temor da possibilidade de ser filho de Omar, resultando em um enigma indecifrável. O leitor é convidado a desvendar múltiplos abismos do ser humano e, assim como o narrador, sente-se dividido quando tenta julgar os gêmeos. Em vários momentos da narrativa, Nael deseja ser como Yaqub, sente vontade que sua identidade esteja ligada ao gêmeo engenheiro e, nesse processo de alteridade, o narrador se vê no outro ou em face de um ser que almeja parecer:

Quando soube que ele [Yaqub] ia chegar, senti uma coisa estranha, fiquei agitado. A imagem que faziam dele era a de um ser perfeito, 
ou de alguém que buscava a perfeição. Pensei nisto: se for ele o meu pai, então sou filho de um homem quase perfeito. A sabedoria dele não me intimidava, nunca tinha sido uma ameaça para mim. Eu o considerava um homem tenaz, respeitado em casa, a ponto de ser elogiado pelo pai, que não sabia até onde o filho queria chegar (HATOUM, 2000, p. 111).

Observa-se, nesse excerto, que, ao se aproximar de Yaqub, Nael experimenta uma sensação inquietante diante do possível alcance da unidade interior. A luta incessante para encontrar o pai e a posição de filho bastardo compõem as fraturas traumáticas da identidade do narrador que, constantemente, se vê como rastro dos gêmeos.

A memória funciona como imagens de histórias e identidades que se definem ou são rasuradas ao longo do relato de Nael. O processo de escavação da memória pode ser lido como recusa do real, como algo imperfeito, pois o narrador utiliza a memória como forma de recuperar imagens e preencher as lacunas. Clément Rosset (1999), em O real e seu duplo, caracteriza a ilusão como um mecanismo de proteção contra a realidade. Para o filósofo, na ilusão, a realidade não é negada, "apenas deslocada, colocada em outro lugar. Mas no que concerne à aptidão para ver, o iludido vê, à sua maneira, tão claro quanto qualquer outro" (ROSSET, 1999, p. 14).

Talvez, por isso, a memória, em Dois irmãos, desloca lembranças e vozes do passado pelo filtro subjetivo de alguém que necessita olhar à sua maneira para entender o presente. Nael, envolvido em suas memórias, recupera as imagens, a casa onde viveu e reconstrói o passado do ponto onde tudo ruiu. O trauma de ser um filho de ninguém, certamente, configura-se como disposição à denegação do real. A memória, então, é metáfora da recusa de uma realidade que se desfez:

Talvez por esquecimento, ele [Halim] omitiu algumas cenas esquisitas, mas a memória inventa, mesmo quando quer ser fiel ao passado... Perdido no passado, sua memória rondava a tarde distante em que o vi recitar os gazais de Abbas. Era um preâmbulo, e Zana se excitava com aquela voz grave, cheia de melodia, que devia tocar a alma dela antes da loucura dos corpos. Omissões, lacunas, esquecimento. O desejo de esquecer. Mas eu me lembro, sempre tive sede de lembranças, de um passado desconhecido, jogado sei lá em que praia do rio (HATOUM, 2000, p. 90-91). 
Nael não está, simplesmente, reinventando sua vida para não esquecer o passado, ele busca estabelecer uma identidade. Daí a necessidade de se reportar constantemente aos mecanismos da memória para imaginar, mesmo que de forma incompleta, uma realidade possível de (re)compor sua origem. Na formação da identidade do narrador, há sempre o processo da alteridade, pois, para legitimar sua fala e ocupar um espaço de direito, Nael precisa da voz do outro e, constantemente, se vê na dualidade dos irmãos gêmeos.

O narrador está dentro e fora da família. Ele é a mistura do indígena com o imigrante, tentando solucionar a problemática de sua identidade. Apesar do apreço por Yaqub, Nael, no fim da narrativa, não sente desejo de ser filho de nenhum dos irmãos gêmeos e o perdão tão esperado fica em suspenso. A conclusão do narrador, ao espelharse no outro, é que tanto Yaqub quanto Omar chegam à ruína pessoal e, independente das escolhas de vida diferentes, eles se parecem:

Lembrava - ainda me lembro - dos poucos momentos em que eu e Yaqub estivemos juntos, da presença dele no meu quarto, quando adoeci. Mas bem antes de sua morte, há cinco anos ou seis anos, a vontade de me distanciar dos dois irmãos foi muito mais forte do que essas lembranças. A loucura da paixão de Omar, suas atitudes desmensuradas contra tudo e todos neste mundo não foram menos danosas do que os projetos de Yaqub: o perigo e a sordidez de sua ambição calculada. Meus sentimentos de perda pertencem aos mortos. Halim, minha mãe. Hoje, penso: sou e não sou filho de Yaqub, e talvez ele tenha compartilhado comigo essa dúvida. O que Halim havia desejado com tanto ardor, os dois irmãos realizaram: nenhum teve filhos. Alguns dos nossos desejos só se cumprem no outro, os pesadelos pertencem a nós mesmos (HATOUM, 2000, p. 263-264).

Sendo assim, o romance não aponta soluções e respostas. A dúvida sobre a origem funciona como metáfora do jogo de duplicidade que engendra da voz do narrador. Dito isto, o terceiro nível do duplo, em Dois irmãos, mantém relação com a configuração espacial da casa e da cidade de Manaus. A casa da família libanesa, em terras amazonenses, configura-se como espelho da terra natal, demonstrando o processo de formação cultural do sujeito que se vê longe das raízes. 
O espaço da casa é primordial para pensar os significados do enredo, é na imagem da casa que o narrador se coloca para contar a vivência de seus moradores e, assim, tentar definir sua identidade em relação aos outros. Para Gaston Bachelard (1993, p. 24), a casa deve ser vista como espaço primordial da vida, já que ela "é o nosso canto do mundo. Ela é, como se diz amiúde, o nosso primeiro universo". Nael reconstrói o que se perdeu da casa da família libanesa e, ao mesmo tempo, preenche o silêncio de cada membro da família em um movimento temporal de recordação e imaginação em torno do espaço vivido.

A casa e a família de Halim sofrem, concomitantemente, o processo de ruína. Se, no passado, a casa representou a ascensão da família libanesa, agora, no tempo da narrativa, é evocada como representação da destruição dos traços identitários dessa mesma família. Para a crítica Juliana Santini (2011), o espaço da casa, no romance de Hatoum, representa a história e a ruína da família, tanto em sua arquitetura quanto nos significados culturais:

Nesse ponto, é necessário considerar um primeiro aspecto relacionado ao binômio identidade/alteridade no interior da narrativa: a casa, a característica da mobília e a trajetória de seus habitantes encerrada nas paredes do prédio delimitam o campo de constituição de uma identidade familiar permeada pela imagem do outro, um outro representado pelo Líbano no espaço de Manaus: a feição subjetiva da família define-se por uma permeabilidade de culturas, marca da adaptação dos costumes trazidos na época da imigração aos elementos típicos da cultura manauara (SANTINI, 2011, p. 96).

A decadência da casa, que é vendida e se transforma em um comércio, revela duplamente a descaracterização da identidade cultural libanesa que se consolidou nos objetos e na rotina da casa, bem como a ruína das relações interpessoais da família de Halim e Zana. O amor excessivo da mãe pelo filho caçula causa a revolta e contribui para alimentar o ódio entre os irmãos. O pai também não suporta ver a proteção da mãe e enxerga nos filhos uma barreira que o separa de sua esposa. Entre disputas de amor e ódio, a casa, paulatinamente, sofre o processo de destruição e, aos poucos, se torna um lugar deserto e repleto de lembranças: 
Depois da morte de Halim, a casa começou a desmoronar. Omar foi ao enterro, mas permaneceu distante, tão distante que o irmão, mesmo ausente, parecia mais próximo da despedida ao pai. Yaqub mandara entregar no cemitério uma coroa de flores e um epitáfio, que Talib traduziu e leu em voz alta: Saudades do meu pai, que mesmo à distância sempre esteve presente.

Os amigos de Halim se emocionaram. Omar, ao ver o choro da mãe, se afastou do túmulo do pai (HATOUM, 2000, p. 220).

O processo de desmoronamento desse espaço inicia-se com a morte de Halim e finda com o derrubar de azulejos, quando a casa é vendida. Zana passa a sentir uma espécie de luto nesse processo e, aos poucos, caminha para a morte. O silêncio e a solidão se instauram na casa, que sofre, assim como as personagens imigrantes, um processo de luto, decorrente da perda das raízes. A marca do tempo está diretamente relacionada ao espaço habitado. Quando a casa é vendida, Zana vê sua vida e sua história sendo levadas embora com a retirada dos móveis:

Poucos dias depois, um caminhão estacionou em frente da casa e os carregadores fizeram a mudança para o bangalô de Rânia. Zana passou a chave na porta do quarto, e do balcão ela viu a lona verde que cobria os móveis de sua intimidade. Viu o altar e a santa de suas noites devotas, e viu todos os objetos de sua vida, antes e depois do casamento com Halim. Nada restou na cozinha nem na sala. Quando ela desceu, a casa parecia um abismo. Caminhou pela sala vazia e pendurou a fotografia de Galib na parede marcada pela forma do altar. Nas paredes nuas, manchas claras assinalavam as coisas ausentes (HATOUM, 2000, p. 252).

Reitera-se, nesse excerto, a duplicidade entre o espaço vivido e as personagens. Da mesma forma que a casa encontra-se em estado de decadência, os seus donos também encontram a morte e, assim, toda uma tradição cultural cede espaço para a formação de uma nova identidade. Além do espaço da casa, a própria cidade de Manaus é evocada, pelo narrador, a partir do entrecruzamento da cultura libanesa com elementos típicos da região amazônica.

A representação estética da cidade de Manaus exibe os cheiros e as imagens de horizontes culturais, marcando o convívio entre 
a população nativa e os imigrantes libaneses com seus sonhos de progresso. Tânia Pellegrini (2007, p. 107) afirma que a narrativa de Hatoum apresenta um universo geográfico exótico e subjetivo: "São como territórios concêntricos, um dentro do outro: a Manaus real e seu duplo, a Manaus imaginária; dentro, a colônia libanesa, no centro da qual as casas das famílias avultam como espaço privilegiado".

Assim, nessa trama, Manaus representa as marcas do tempo subjetivo, das memórias do narrador, em uma relação dialética com o tempo da história brasileira - do ciclo da borracha com o sonho de progresso a qualquer preço ao autoritarismo da ditadura militar. Como um espelho do que é narrado, tem-se a imagem de um passado histórico e político do Brasil:

Noites de blecaute no norte, enquanto a nova capital do país estava sendo inaugurada. A euforia, que vinha de um Brasil tão distante, chegava a Manaus como um sopro amornado. E o futuro, ou a ideia de um futuro promissor, dissolvia-se no mormaço amazônico. Estávamos longe da era industrial e mais longe ainda do nosso passado grandioso (HATOUM, 2000, p. 128).

Percebe-se, nesse excerto, o tempo da história brasileira que surge do tempo subjetivo das lembranças do narrador. Os conflitos internos do eu que narra, buscando definir-se na imagem dos gêmeos, refletem, no tempo narrado, os conflitos da região Norte com o processo de modernização das capitais - uma ideologia utópica do início do século XX. Nessa leitura da duplicidade espacial, que o romance apresenta, é importante observar a relação dos gêmeos com os lugares que percorrem, pois nessas representações cada irmão se liga de maneira diferente em relação à casa e à cidade. Omar não sonha em abandonar Manaus ou a casa da infância, ele sempre se relaciona com o presente e os prazeres momentâneos. Já Yaqub almeja o futuro promissor, planeja sair da casa e da cidade flutuante.

Nesse sentido, o espaço reflete quem a personagem é e como ela age. Por um lado, Omar, o protegido da mãe, exala os cheiros, os traços peculiares de Manaus e, por extensão, representa, também, a estagnação e o atraso do desenvolvimento no Norte do país. Por outro lado, Yaqub parece não conseguir perdoar a mãe por ter preferido enviá- 
lo para o Líbano e muda-se para São Paulo em busca de mudar sua vida. A relação com a capital representa o avanço e a modernização, tanto no espaço da cidade quanto na vida dele.

Os gêmeos não conseguem conviver no mesmo ambiente. Para tanto, Omar está sempre ligado à casa - espaço, sobretudo, da identidade da família libanesa -, na mesma medida em que se sente parte da cidade de Manaus. A cidade - com a qual se confunde a imagem do Caçula - expõe os descaminhos e os contornos de projetos e sonhos interrompidos. No caso de Yaqub, a ida para São Paulo representa sua independência em relação à família, pois só assim conseguiria conviver com a dor da rejeição da mãe. A metrópole - que sem dúvida é o símbolo do avanço - torna possível os desejos e os planos de Yaqub.

De um lado, convergem a ambição de Yaqub e a modernização de São Paulo; de outro lado, as desventuras de Omar e uma Manaus "que se mutilava e crescia ao mesmo tempo, afastada do porto e do rio, irreconciliável com o seu passado" (HATOUM, 2000, p. 264). Nem o espaço nem os gêmeos, nas palavras do narrador, encontram uma unidade ao fim do romance.

Portanto, o narrador, contemplando o movimento das águas que cercam Manaus, lembra o tempo passado, transfigurando para o presente da narração as imagens subjetivas. Simbolicamente, essa memória fraturada revela-se como uma abertura que liga o presente do narrador com seu passado, na medida em que ele, ao mesmo tempo em que recorda as vivências e busca sua origem, avalia cada personagem e suas atitudes. Assim, num movimento temporal, o romance não se estrutura apenas no clássico duplo dos irmãos gêmeos, como, também, consegue mobilizar as questões ligadas à identidade e à subjetividade do ser humano - que, na contemporaneidade, ressurgem como tema caro à literatura.

FRATURATED IDENTITIES: VARIATIONS OF DOUBLE IN TWO BROTHERS, BY Milton Hatoum

\section{ABSTRACT}

In this article, we propose an analysis of the variations of the double myth in Milton Hatoum's novel Two Brothers, published in 2000. Based on the theoretical and critical assumptions from Bravo (1997), Rank (2013), Bachelard 
(1993), Rosset (1999) and Freud (1996), it is intended to demonstrate that in addition to the theme of the twin brothers the double, in Two Brothers, can be read in two other aspects of duplicity: the narrator configuration, which tries to define its identity as mirror other; and the image of the house in ruins, a space that doubly reflects the decadence of the Lebanese family, as well as the immigrant's cultural identity on the land of others.

KeYwORDS: twins, narrator, space, memory.

IDENTIDADES FRACTURADAS: VARIACIONES DEL DOBLE EN DOIS IRMÃOS, de Milton Hatoum

\section{RESUMEN}

En este artículo, proponemos un análisis de las variaciones del mito del doble en la novela Dois irmãos, de Milton Hatoum, publicado en 2000. Con base en las conjeturas teórico-críticas de Bravo (1997), Rank (2013), Bachelard (1993), Rosset (1999) y Freud (1999) (1996), pretendemos demostrar que, además del tema de los hermanos gemelos, el doble, en Dois irmãos, puede ser leído en dos aspectos de duplicidad: la configuración del narrador, que intenta definir su identidad como espejo del espejo del otro; y la imagen de la casa en ruinas, espacio que refleja doblemente la decadencia de la familia libanesa, así como la identidad cultural del inmigrante en tierra ajena.

PALABRAS ClaVE: gemelos, narrador, espacio, memoria.

\section{NOTAS}

1. O termo "pós-moderno" é utilizado, aqui, como referência aos estudos de Stuart Hall (2006) sobre a identidade cultural do indivíduo nos dias atuais. Existem vários estudos teóricos e críticos que discutem as conceituações acerca da modernidade, da pós-modernidade ou do pós-modernismo. Entretanto, não é nosso objetivo discutir e problematizar esses conceitos neste artigo.

2. A intertextualidade entre as histórias bíblicas e o romance de Hatoum é analisada por Benedito Nunes (2007) em seu texto intitulado "Volta ao mito na ficção brasileira". Nunes (2007) faz um percurso histórico e demonstra 
a recorrência ao mito das origens na literatura brasileira, usando como exemplo as ficções de Raduan Nassar, Machado de Assis, Mário de Andrade e Milton Hatoum. Maria da Luz Pinheiro de Cristo (2007) e Leyla PerroneMoisés (2007), em ensaios sobre a obra de Milton Hatoum, também se valem da intertextualidade bíblica para analisar o romance Dois irmãos.

\section{REFERÊNCIAS}

BACHELARD, G. A poética do espaço. Tradução Antonio de Pádua Danesi. São Paulo: Martins Fontes, 1993.

BAUMAN, Z. Identidade: entrevista a Benedetto Vecchi. Tradução Carlos Alberto Medeiros. Rio de Janeiro: Jorge Zahar Ed., 2005.

BRAVO, N. F. Duplo. In: BRUNEL, Pierre (Org.). Dicionário de mitos literários. Tradução Carlos Sussekind et al. Rio de Janeiro: José Olympio, 1997. p. 261-288.

FREUD, S. O estranho. In:__. Obras completas. Tradução Jayme Salomão. Rio de Janeiro. Imago, 1996.

HALL, S. A identidade cultural na pós-modernidade. Tradução Tomaz Tadeu da Silva e Guacira Lopes Louro. Rio de Janeiro: DP\&A, 2006.

HATOUM, M. Dois irmãos. São Paulo: Companhia das Letras, 2000.

MELLO, A. M. L. de. As faces do duplo na literatura. In: INDURSKY, Freda; CAMPOS, Maria do Carmo. (Org.). Discurso, memória, identidade. Porto Alegre: Sagra Luzzato, 2000, p. 111-123.

NUNES, B. Volta ao Mito na ficção brasileira. In: CRISTO, M. da Luz P. de (Org.). Arquitetura da memória. Manaus: Editora da Universidade Federal do Amazonas/UNINORTE, 2007. p. 207-218.

PELLEGRINI, T. Milton Hatoum e o regionalismo revisitado. In: CRISTO, M. da Luz P. de (Org.). Arquitetura da memória. Manaus: Editora da Universidade Federal do Amazonas/ UNINORTE, 2007. p. 98-118.

PERRONE-MOISÉS, L. A cidade flutuante. In: CRISTO, M. da Luz P. de (Org.). Arquitetura da memória. Manaus: Editora da Universidade Federal do Amazonas/UNINORTE, 2007. p. 284-289.

RANK, O. $O$ duplo: um estudo psicanalítico. Tradução Erica Sofia Luísa Foerthmann Schultz et al. Porto Alegre: Dublinense, 2013.

ROSSET, C. O real e seu duplo: ensaio sobre a ilusão. Tradução José Thomaz Brum. Porto Alegre: L\&PM, 1999. 
SANTINI, J. Espaço, tempo, identidade: a figura da casa no romance Dois irmãos, de Milton Hatoum. In: CAMARGO, F. P.; CARDOSO, J. B. (Org.). Percursos da narrativa brasileira contemporânea. Goiânia: Editora da PUC Goiás, 2011.

Submetido em 12 de janeiro de 2018

Aceito em 1 de março de 2018

Publicado em 31 de agosto de 2018 